\title{
Titles I \& IV of the LMRDA: A Resolution of the Conflict of Remedies
}

Union election practices may violate provisions of Titles $\mathrm{I}^{1}$ and $I^{2}$ of the Labor-Management Reporting and Disclosure Act of $1959^{3}$ (LMRDA) concurrently. Title I, embodying the "Members" Bill of Rights," guarantees each member an equal right to nominate and vote within the union ${ }^{4}$ and freedom of speech and assembly in union affairs, ${ }^{5}$ while Title IV imposes specific requirements for the conduct of union elections. ${ }^{6}$ Despite this substantive overlap, the procedures for enforcement of the Titles differ fundamentally: Title $\mathrm{I}$ is enforced by civil actions filed by members

1. 29 U.S.C. $\S \S 411-15$ (1970).

2. Id. $\S \S 481-83$.

3. Id. $\$ \S 153,158-60,186,401-531$ (1970) [hereinafter cited as the LMRDA].

4. Every member of a labor organization shall have equal rights and privileges within such organization to nominate candidates, to vote in elections or referendums of the labor organization, to attend membership meetings, and to participate in the deliberations of such meetings, subject to reasonable rules and regulations in such organization's constitution and bylaws.

LMRDA § 101(a)(1), 29 U.S.C. § 411(a)(1) (1970).

5. Every member of any labor organization shall have the right to meet and assemble freely with other members; and to express any view's, arguments, or opinions, and to express at meetings of the labor organization his view's, upon candidates in any election of the labor organization or upon any business properly before the meeting, subject to the organization's established and reasonable rules pertaining to the conduct of the meetings: Provided, That nothing herein shall be construed to impair the right of a labor organization to adopt and enforce reasonable rules as to the responsibility of every member toward the organization as an institution and to his refraining from conduct that would interfere with its performance of its legal or contractual obligations.

Id. § 101(a)(2), 29 U.S.C. $\$ 411(\mathrm{a})(2)$ (1970).

The types of rules that are "reasonable" under the proviso have not been established. See generally Redding, Democracy, Collective Bargaining and LMRDA, in SyMPosIuM oN LMRDA: The Labor-Management Reporting and Disclosure Act of 1959, at 159, 210 (R. Slovenko ed. 1961) [hereinafter cited as Symposium].

6. In any election ... a reasonable opportunity shall be given for the nomination of candidates and every member in good standing shall be eligible to be a candidate and to hold office (subject to $\S 504$ of this title and to reasonable qualifications uniformly imposed) and shall have the right to vote for or otherwise support the candidate or candidates of his choice, without being subject to penalty, discipline, or improper interference or reprisal of any kind by such organization or any member thereof .... Each member in good standing shall be entitled to one vote. No member whose dues have been withheld by his employer for payment to such organization pursuant to his voluntary authorization provided for in a collective bargaining agreement shall be declared ineligible to vote or be a candidate for office in such organization by reason of alleged delay or default in the payment of dues .... The election shall be conducted in accordance with the constitution and bylaws of such organization ....

LMRDA § $401(\mathrm{e}), 29$ U.S.C. § 481(e) (1970). 
whose rights are infringed, ${ }^{7}$ but a member alleging violations under Title IV is limited to filing a complaint, after exhausting his intra-union remedies, with the Secretary of Labor, ${ }^{8}$ who may then file an enforcement suit. ${ }^{9}$

Some courts, recognizing the general legislative intention that the LMRDA authorize only minimal federal intervention into internal union affairs, ${ }^{10}$ have held that private enforcement of Title I in overlap cases is preempted by the enforcement procedure of Title IV. ${ }^{11}$ Commentators have argued that private remedies for violations of Title I are both necessary for effective enforcement of the LMRDA and permissible within the terms of the Act and the intent of Congress, at least where the private enforcement suit is brought prior to a union election. ${ }^{12}$ Post-election private remedies have been held to be barred by LMRDA section $403,{ }^{13}$ which states that " $[t]$ he remedy provided by [Title IV] . . . for challenging an election already conducted"-a suit by the Secretary of Labor to set aside the election-"shall be exclusive."14 This reading of the

7. Section 102 permits a civil action "for such relief (including injunctions) as may be appropriate." Id. \$ 102, 29 U.S.C. $\$ 412$ (1970).

8. Id. § 402(a), 29 U.S.C. $\$ 482$ (a) (1970).

9. (b) The Secretary shall investigate such complaint and, if he finds probable cause to believe that a violation of this subchapter has occurred, and has not been remedied, he shall ... bring a civil action against the labor organization ... to set aside the invalid election ....

(c) If, upon a preponderance of the evidence after a trial upon the merits, the court finds-

(2) that the violation of section 481 of this title may have affected the outcome of an election,

the court shall declare the election, if any, to be void and direct the conduct of a new election under supervision of the Secretary.

Id. $\S \S 402$ (b), (c), 29 U.S.C. $\S \S 482$ (b), (c) (1970).

10. See text and notes at notes 64-72 infra. The minimization of intervention by requiring Title IV complaints to be screened through the Secretary of Labor has, under some criteria, rendered enforcement of the substantive guarantees of the LMRDA ineffectual. See Beaird, Union Officer Election Provisions of the Labor-Management Reporting and Disclosure Act of 1959, 51 V. L. Rev. 1306, 1325-26 (1965); Note, Pre-Election Remedies Under the Landrum-Griffin Act: The "Turilight Zone" Betureen Election Rights Under Title $I V$ and the Guarantees of Tilles $I$ and V, 74 Colum. L. Rev. 1105, $1114-21$ (1974) [hereinafter cited as Columbia Note].

1I. See, e.g., Driscoll v. Operating Engineers Local 139, 484 F.2d 682 (7th Cir. 1973); Robins v. Rarback, 325 F.2d 929 (2d Cir. 1963); cases cited note 32 infra.

12. See, e.g., Berchem, Labor Democracy in America: The Impact of Tilles $I$ \& $I V$ of the Landrum-Griffin Act, 13 VILL. L. REv. 1, 10 (1967); Etelson \& Smith, Union Discipline Under the Landrum-Griffin Act, 82 HARv. L. Rev. 727, 740 (1969); Columbia Note, supra note 10, at 1112-21; Comment. Union Elections and the LMRDA: Thirteen Years of Use and Abuse, 81 YALE L.J. 407, 495-503 (1972) [hereinafter cited as YALE CoMment].

13. Kempthorne v. United Transp. Union. 457 F.2d 551 (7th Cir. 1972); Colpo v. Highway Truck Drivers Local 107. 305 F.2d 362 (3d Cir. 1962); see Driscoll v. Operating Engineers Local 139, 484 F.2d 682, 688 n.11 (7th Cir. 1973).

14. LMRDA $\$ 403,29$ U.S.C. $\S 483$ (1970). 
statute, however, is improper insofar as it requires preclusion of all private enforcement suits brought or pending after the conclusion of an election. Suits by union members that state clear violations of Title I and seek remedies other than setting aside an election should not be foreclosed either because of substantive overlap with Title IV or because of section 403's narrow rule of remedial preclusion.

This comment first examines the evolution of the judicial response to the interplay between Title I and Title IV, identifying three alternative approaches to overlap cases. It then evaluates the legislative history of the LMRDA as evidence of the intended operation of the Act's enforcement scheme. The comment concludes that a court presented with a union member's suit for violation of his rights in connection with a union election must first determine the sufficiency of the allegations under Title I, independently of any consideration of their possible sufficiency under Title IV, and apply a rule of preclusion only to the remedy of setting aside an election already conducted.

\section{The Judicial Response to the Interplay Problem}

\section{A. Early Judicial Treatment of Overlap Cases}

Two different approaches to overlap cases had appeared prior to 1964: first, analysis of Title I claims independently of the presence of Title IV claims, and second, preclusion of Title I claims by Title IV remedies. An example of the first approach is Beckman v. Local 46 , Bridge Workers, ${ }^{15}$ a member's suit alleging a violation of the equal right to vote provision of section 101(a)(1) of the Members' Bill of Rights. The Seventh Circuit upheld a preliminary injunction restraining the removal of a ballot box and the counting of the ballots, rejecting the defendant's assertion that because the allegations concerned election abuses, the only proper procedure for redress was the scheme outlined in Title IV. The court ruled that there could be no preclusion by Title IV when the election abuse affected individual rights protected by Title $\mathrm{I}^{16}$

The Second Circuit reached a different result in Robins $v$. Rarback, ${ }^{17}$ dismissing a complaint alleging Title I violations for fail-

15. 314 F.2d 848 (7th Cir. 1963).

16. Id. at 850 .

17. 325 F.2d 929 (2d Cir. 1963). A different panel of the Second Circuit had held only a month earlier, in Harvey v. Calhoon, 324 F.2d 486 (2d Cir. 1963), that the denial of "equal rights . . to nominate" under Title I could be the subject of a private suit for injunction regardless of whether there was also a denial of "a reasonable opportunity ... for the 
ure to state a cause of action. ${ }^{18}$ Plaintiffs had argued that an equal right to vote necessarily encompassed the right to cast an effective vote, and that a vote could not be effective unless the election was properly conducted in all its aspects. The court expressed doubt that the allegations of enumerated "electoral abuses" were sufficient under Title I, but held that since they would be proper under Title IV, and since Congress intended that Title IV be enforced only through the Secretary of Labor, it could not grant an injunction against the abusive election procedures in a private enforcement suit for the violation of voting rights that stemmed from them. ${ }^{19}$ In essence, the court allowed the exclusivity of the Title IV remedy to preclude substantive claims under Title $I,{ }^{20}$ rather than examining the complaint for sufficiency under Title I independently of its possible sufficiency under Title IV as the Beckman court had done.

\section{B. Calhoon v. Harvey}

In 1964, the Supreme Court granted certiorari in Calhoon $v$. Harvey ${ }^{21}$ to resolve the conflicts and confusion existing in the ap-

nomination of candidates" under Tittle IV.Id. at 489. The Robins court distinguished its own case on the ground that more extensive interference with election procedures was sought. 325 F.2d at 931 . But see Calhoon v. Harvey, 379 U.S. 134 (1964), rev'g 324 F.2d 486 (2d Cir. 1963), discussed in text at notes 21-32 infra.

18. The court also dismissed as moot an appeal from the denial of a preliminary injunction that would have required certain procedures to be followed in the election, since an election had been held six months prior to the decision on appeal. $325 \mathrm{~F} .2 \mathrm{~d}$ at 929 . Compare Judge Waterman's statement in concurrence that the proper ground for dismissing the complaint altogether was the fact that the next election would not be held for another six months, and plaintiff's rights, therefore, had not already been violated, thus precluding his invocation of Title I. Id. at 933-34 (Waterman J., concurring).

19. Id. at 931 . The problem with this analysis is that Congress never considered the conflict between the enforcement procedures of the two titles, and the substantive preclusion implied by the court's holding is thus not strongly supported. See text and notes at notes 56-80 infra.

20. Cf. Mamula v. United Steelworkers, 304 F.2d 108 (3d Cir. 1962), in which a union president had sued to enjoin an election on the ground that the union's constitution and bylaws failed to prescribe procedures to be followed in selecting nominees, and that he had, therefore, been denied his section 101(a)(1) equal right to submit his name for candidacy. The court reversed the district court's decree setting aside the election, which had subsequently taken place, on the ground that the specific and comprehensive coverage of nomination and election procedures in Title IV compelled the conclusion that it, not Title I, provided the substantive standards governing the facts at hand. The court considered the exclusivity of Title IV's enforcement scheme in concluding that plaintiff had no standing, but did not make clear whether it also relied on that exclusivity of remedy in determining the substantive scope of Title I. Arguably, a more proper ground for the decision would have been the specific preclusion of the remedy of setting aside an election under section 403,29 U.S.C. $\$ 483$ (1970), rather than preclusion of the substantive Title I claim. See text and notes at notes $81-87$ infra.

21. 379 U.S. 134 (1964). 
proaches applied by the courts of appeals to the interplay problem. ${ }^{22}$ Calhoon involved a challenge by individual union members to union rules that had the effect of depriving all but the incumbents and a few others of eligibility for nomination for union office. $^{23}$ The relief sought included damages and an injunction against elections until the union revised its nomination system. ${ }^{24}$ The Supreme Court first considered the substantive scope of Title I and held that the equal right to nominate candidates does not encompass a right to nominate anyone, regardless of his eligibility. The members' challenge, the Court said, was directed at eligibility rules that were themselves applied without discrimination. ${ }^{25}$ That challenge could not be maintained under Title I, although possible violations of Title IV might be established.

In the second part of its opinion, the Court held that allegations of a Title IV violation alone could not establish jurisdiction for a private suit under Title I, and that the Secretary of Labor's right to prosecute Title IV suits was exclusive. ${ }^{26}$ The Court stated that Congress had "decided not to permit individuals to block or delay union election by filing federal-court suits for violation of Title IV,"27 Since the allegations in Calhoon were insufficient under Title I, even if it were assumed that they established violations of Title IV, the members were not the proper plaintiffs in an enforcement suit. This statement was not made to support the proposition that Title IV enforcement procedures control overlap suits in which both Title I and Title IV claims are presented, but to overrule the court of appeals, which had held that Title IV allegations could be considered in determining the sufficiency of a Title I complaint. ${ }^{28}$ The holding of the Court was limited to a definition of the relative substantive scopes of Titles I and IV and a distinctly separate consideration of the exclusivity of enforcement when only Title IV claims exist. The Court did not hold that the existence of putative Title IV claims precludes an individual member's suit when the Title I allegations are themselves sufficient.

22. Id. at 137.

23. Only those who had been members of the marine engineers' union for five years and who had accumulated a certain amount of qualifying seatime or time as a union officer in years prior to the election were eligible. See Harvey v. Calhoon, 221 F. Supp. 545, 546 (S.D.N.Y. 1963).

24. 379 U.S. at $136 \&$ n.4.

25. Id. at 139 .

26. Id. at $139-40$.

27. Id. at 140. The general exclusion of private suits under Title IV is subject to a single exception under section 401 (c), 29 U.S.C. $\$ 481$ (c) (1970), which gives any bona fide candidate for union office a right to pre-election suit to acquire voting lists held by the union.

28. 379 U.S. at $140-41$. 
Although Calhoon's narrow interpretation of the scope of Title I restricts the number of cases in which individual suits may be brought, ${ }^{29}$ cases still arise in which election procedures in violation of Title IV also have a discriminatory impact on voting or nominating rights or deny the right of free speech, and in which a true overlap would thus exist. ${ }^{30}$ In such cases, Calhoon does not apply, and preclusion of substantive Title I claims by the remedial exclusivity of Title IV would be improper.

\section{Judicial Approaches in Overlap Cases Since Calhoon}

1. Preclusion of Title I Remedies. Driscoll v. Operating Engineers Local $139^{31}$ illustrates the broad preclusive effect some courts have given Title IV under the authority of Calhoon. ${ }^{32} \mathrm{~A}$ union bylaw requiring each candidate for union office to file an anticommunist affidavit was challenged as violating both the free speech $^{33}$ and equal rights ${ }^{34}$ provisions of Title I, the Members' Bill of Rights. The Seventh Circuit held that the Title I remedy was precluded because of the overlapping coverage of Title IV, whether an election had been held or was yet to be held, and that the complaint should be dismissed for want of jurisdiction. ${ }^{35}$

The plaintiff in Driscoll attempted to distinguish Calhoon on the ground that the latter case involved alleged violations of only the equal right to nominate and not of the free speech guarantee as well. $^{36}$ The court rejected this distinction, however, and stated, without any direct consideration of the allegations' independent

29. A broad application of the Calhoon holding to other Title I claims not technically controlled by the case, such as alleged denials of free speech under section 101(a)(2), would considerably reduce the substantive effect of Title I. See generally text and notes at notes 31-50 infra. Several commentators have suggested that Calhoon be overruled or narrowly read to avoid that result. See, e.g., Berchem, supra note 12, at 10; Columbia Note, supra note 10 , at $1112 \&$ n.45; Yale Comment, supra note 12 at 551 . See also Comment, Fair Election Procedures under the Labor-Management Reporting and Disclosure Act of 1959 and the United Mine Workers, 6 Colum. J.L. \& Soc. ProB. 76, 80 (1970).

30. Cf. Kleiler, The Impact of Titles I-VI of the Landrum-Griffin Act, 3 GA. L. REv. 378, 379 (1969), noting that nearly as many suits had been filed prior to 1969 under Title I as under all other sections of the LMRDA. The number of potential overlap suits can be assumed to be significant. See also cases cited at note 32 infra.

31. 484 F.2d 682 (7th Cir. 1973), cert. denied, 415 U.S. 960 (1974).

32. See, e.g., McDonough v. Local 825, Operating Engineers, 470 F.2d 261, 264 (3d Cir. 1972); McGuire v. Brotherhood of Locomotive Engineers, 426 F.2d 504, 507-08 (6th Cir. 1970); Spivey v. Trainmen, No. 10317,69 L.R.R.M. 2709 (N.D. Ga. 1968); McArthy v. District 9 Machinists, 252 F. Supp. 350, 352 (D. Mo. 1966); Verbiscus v. Local 49, Marine Workers, 238 F. Supp. 848, 849-50 (E.D. Mich. 1964).

33. LMRDA \$ 101(a)(2), 29 U.S.C. \$ 411 (a)(2) (1970). See note 5 supra.

34. Id. $\$ 101(\mathrm{a})(1), 29$ U.S.C. $\$ 411(\mathrm{a})(1)(1970)$. See note 4 supra.

35. $484 \mathrm{~F} .2 \mathrm{~d}$ at $688 \mathrm{n} .11$.

36. Id. 
sufficiency under Title I, that the allegations were outside the court's jurisdiction in a private suit, since they "basically related" to eligibility within Title IV. ${ }^{37}$ This holding misapplies Calhoon, in which the Court construed the provisions of the equal rights section directly rather than relying solely on the possible sufficiency of the allegations under Title IV. Although the presence of Title IV allegations in Calhoon could not give the court jurisdiction under Title I, ${ }^{38}$ the presence of Title IV allegations in Driscoll should not have foreclosed it. If the complaint established a prima facie violation of the member's right to "express any views," ${ }^{39}$ the court should have taken jurisdiction in an action to declare the violative rule void under the explicit provisions of Title $\mathrm{I}^{40}$

Under the court's holding in Driscoll, whenever allegations of the violation of protected individual rights in connection with an election "basically relate" to Title IV, suits by members under Title I are precluded. The individual member's remedy under Title IV, further, must be postponed until after an election is held, at which point he is limited to filing a complaint with the Secretary of Labor. ${ }^{41}$ Through this chain of reasoning, vindication of certain rights of union members under Title $I$ is virtually foreclosed. Where the alleged violation of Titles I and IV stems from provisions of the union rules, it affects individual rights without relation to any particular election. If a litigant is not permitted to bring an action under Title I before an election and has his Title I remedies mooted by the occurrence of the election, the abuse can continue indefinitely unless the Secretary of Labor agrees to bring suit ${ }^{42}$ and the court finds that the abuse may have affected the outcome of the election. ${ }^{43}$

Such cases need not be viewed in a pre- or post-election context at all. ${ }^{44}$ Section 403 specifically provides that the remedy for chal-

37. Id.

38. See text at note 26 supra.

39. LMRDA \& 10I(a)(2), 29 U.S.C. $\S 41 \mathrm{I}(\mathrm{a})(2)$ (1970).

40. See id. $\$ 101(b), 29$ U.S.C. $\S 411$ (b) (1970), declaring void any provision of the union constitution or bylaws that is inconsistent with the guarantees of section 101 .

41. See 484 F.2d at 688; Venet v. Local 606, Carpenters, 342 F. Supp. 819, 820 (D. Minn. 1972); text and notes at notes 8-9 supra.

42. During the years 1967 to 1972 , the Secretary brought suit in only twenty-four to forty-five percent of complaints in which he had made a determination of probable cause that a violation had occurred. See Columbia Note, supra note 10, 111 8-19 \& n.83.

43. This is the standard for setting aside an election. LMRDA $\S 402$ (c)(2); 29 U.S.C. \$ 482(c)(2) (1970), quoted at note 9, supra.

44. Compare Kempthorne v. United Transportation Union, 457 F.2d 551 (7th Cir. 1972), with Amalgamated Clothing Workers Rank \& File v. Amalgamated Clothing Workers, Joint Board, 473 F.2d 1303 (3d Cir. 1973). 
lenging a conducted election is exclusive, not that the occurrence of an election bars all other actions; the exclusivity principle properly operates only when the member seeks relief against a conducted election.

2. The "Articulated Policy of Suppression" Requirement. The Second Circuit, in Schonfeld $v$. Penza ${ }^{45}$ forged a modified view of the extent to which Title IV precludes Title I suits. The case involved suits seeking to restrain the union from enforcing penalties imposed upon Schonfeld, a former union officer, after a trial held by the union. The sanctions included removal from office and a declaration that he was ineligible to run for union office for five years. Schonfeld alleged that the trial had been unfairly run and that its purpose was to limit his efforts to "democratize" the union. ${ }^{46}$

The court viewed the complaint as containing two severable components-a claim that Schonfeld's ineligibility denied union members the equal right to vote and nominate, and a claim that the sanctions denied Schonfeld and others their right of free speech. The first claim was analyzed, under Calhoon, as involving no discrimination and therefore not being within the jurisdiction of the court in a section 101(a)(1) suit. ${ }^{47}$ As the court then proceeded, properly, to evaluate the sufficiency of the allegations independently under section 101(a)(2), it articulated an intermediate approach to the interplay problem. The court stated that in reconciling "Title I rights and Title IV procedural requirements," it would intervene in union activities only where the alleged violation of both Titles could be said, "as a result of established union history or articulated policy, to be part of a purposeful and deliberate attempt by union officials to suppress dissent within the union." 48

Once it is recognized that certain overlap cases are cognizable in federal court at the instance of an individual union member, a test of purposeful and articulated suppression is not the proper method for determining whether a given case falls within that category. That test does not appear in Title I, which guarantees members' rights against abridgement by any discrimination or suppression, not only that resulting from "articulated policy."49

45. 477 F.2d 899 (2d Cir. 1973).

46. Id. at 901 .

47. Id. at 902 .

48. Id. at 904. Courts within the Second Circuit have consistently applied this test. See, e.g., Fritsch v. District 9, Painters, 493 F.2d 1061 (2d Cir. 1974); Russo v. Local 676, Plumbers, 372 F. Supp. I265 (D. Conn. 1974); Schonfeld v. Raftery, 335 F. Supp. 846 (S.D.N.Y. 1971).

49. Moreover, there is no statutory support for requiring a member to prove intent only in cases in which the violation occurred in relation to an election. 
The effect of Schonfeld's additional requirement is a partial substantive preclusion of section 101(a)(2) claims. ${ }^{50}$

3. Independent Analysis of Claims. The third post-Calhoon approach to the interplay problem, which has received little attention, involves a simple, straightforward analysis like that applied by the Third Circuit in Depew v. Edmiston. ${ }^{51}$ The plaintiffs in Depew had nominated one plaintiff, Caldarelli, to run for office in the Trainmen's Union. Caldarelli was declared ineligible on the basis of a bylaw that required those members restricted to yardwork, as he was, to transfer to another local. The plaintiffs alleged a violation of the equal rights provision of Title I on the ground that the bylaw was enforced in a discriminatory fashion and sought to enjoin a scheduled election. The circuit court held that the district court had jurisdiction to determine whether the alleged discrimination had occurred. ${ }^{52}$

Although the alleged violations related to eligibility requirements, which are covered by Title IV, the court found sufficient allegations of discrimination to raise a prima facie independent violation of Title I. ${ }^{53}$ The case thus involved a true overlap, in contrast with the Calhoon case, and the court did not apply a rule of substantive preclusion of Title I claims. This approach is in accord with the legislative history and language of the statute, which indicate the distinctiveness of Title I and Title IV procedures and substantive rights. The court of appeals directed the district court on remand to consider the substantiality of the claims under section $101(\mathrm{a})(1)$, without reference to their possible sufficiency under Title IV. ${ }^{54}$

These divergent approaches to overlap cases after Calhoon indicate continued confusion and conflict in the lower courts. Some courts have given effect to Calhoon through a rule of preclusion of Title I claims where Title IV also applies. The shortcomings of this expanded Calhoon rule in assuring consistent protection of statutory rights have been enumerated and discussed elsewhere. ${ }^{55}$ The

50. Cf. Driscoll v. Operating Engineers Local 139, 484 F.2d 682, 687-88 (7th Cir. 1973), recognizing the Schonfeld test as the sole exception to "the broad mandate of Calloon," and finding the test not satisfied on the facts before it. See also Schonfeld v. Raftery, 359 F. Supp. 380 (S.D.N.Y. 1973), aff'd sub nom. Fritsch v. District 9, Painters, 493 F.2d 1061 (2d Cir. 1974).

51. 386 F.2d 710 (3d Cir. 1967).

52. Id. at 715 .

53. See id. at 714 \& n.8.

54. Id at 715 .

55. See authorities cited at notes $10 \& 12$ supra. 
minority approach in overlap cases, based on independent evaluation of the sufficiency of the allegations under Title $I$ and on preclusion only of the private remedy of setting aside an election already held, would avoid these shortcomings and yet be consistent with the legislative history of the LMRDA.

\section{The Legislative History of the LMRDA and the INTERPlay Problem}

The legislative history of the LMRDA does not conclusively explicate the intended relationship of Titles I and IV, because Congress never seriously considered the interplay question; indeed, Congress was barely aware of its existence. ${ }^{56}$ Although both titles were products of the McClellan hearings of 1958, the provisions that now comprise Title IV were drafted, debated, and approved by the Senate before Title I was introduced. ${ }^{57}$ Congress's intention that suit by the Secretary of Labor be the exclusive post-election remedy under Title IV cannot, therefore, be extended to Title I suits in the absence of specific provision for such an extension. Only affirmative evidence from the legislative history of Title I could require that extension. Affirmative evidence would also be required to justify subsuming Title I's enforcement procedures under those of Title IV in the pre-election overlap cases. Neither

56. A speech by Representative McCormack marked one of the few instances of recognition of a potential interplay problem:

It would appear that the choice of a civil suit by an aggrieved member for violations of Title I was a deliberate alternative to a civil suit by the Secretary of Labor on behalf of an aggrieved member. For example, title IV of the Landrum-Griffin bill, like the committee bill, substitutes a civil suit by an aggrieved individual in lieu of a suit by the Secretary of Labor such as is provided in the Senate passed bill [for Title IV]. Yet both types of suits are authorized with respect to the rights granted by title I. The result is conflict and confusion.

105 Cong. REC. 15836 (1959). Unfortunately, this brief mention of the potential problem did not spark serious debate of the issue.

57. The LMRDA went through several successive formulations before the Members' Bill of Rights was added. Senator Kennedy introduced S. 3454, 85th Cong., 2d Sess. (1958), followed by S. 3751, 85th Cong., 2d Sess. (1958). These were combined with the other bills pending in the Senate Labor Committee into one bill, S. 3974, 85th Cong., 2d Sess. (1958). S. ReP. No. 1684, 85 th Cong., 2d Sess. (1958). This bill, which became known as the Kennedy-Ives Bill, was passed by the Senate by a vote of 88-1 on June 23, 1958, 104 Cong. Rec. 11486 (1958), but was killed by the House on Aug. 18, 1958, 104 Cong. Rec. 18288 (1958).

On January 20, 1959, Senator Kennedy introduced the Kennedy-Ervin Bill, S. 505, 86th Cong., lst Sess. (1959). After a number of changes were made by the Senate Committee on Labor and Public Welfare, the bill was renumbered S. 1555 and introduced as a "clean bill" on March 25. 1959. The bill was reported out by the committee on April 14, still without a Members' Bill of Rights. The Bill of Rights was finally added on April 21, and the entire bill was passed by the Senate on April 25. Thus, for most of the time it was being considered, the labor reform legislation did not have a Members' Bill of Rights. 
of these conclusions can be supported; instead, the available evidence indicates a congressional intention that Title I rights be fully enforced.

The Select Committee on Improper Activities in the Labor or Management Field (the McClellan Committee) extensively investigated the abuses of union leaders and the relation of organized crime to organized labor, ${ }^{58}$ ultimately finding "a significant lack of democratic procedures in the unions studied." 59 The Committee, in order to insure union democracy, recommended federal legislation guaranteeing and regulating union elections. ${ }^{60}$ This recommendation formed the basis of what was to become Title IV of the LMRDA. ${ }^{61}$

The substantive provisions of Title IV did not change significantly in the successive forms of the Senate bill, ${ }^{62}$ and the substantive provisions of the House bill were nearly identical to those of the Senate bill. ${ }^{63}$ The method of enforcement, however, changed significantly as the Act took shape.

The administrative enforcement provisions of the present Title IV had first been included in a bill introduced by Senator Kennedy in 1958 and reintroduced in $1959 .{ }^{64}$ The Senate later rejected a bill offered by Senator Goldwater that was designed to give individual members as well as the Secretary of Labor the power to sue to enforce Title IV. ${ }^{65}$ The Supreme Court, in Trbovich $v$. UMW, ${ }^{66}$ later summarized the Senate's reason for this rejection as the fear that unions would be required to defend themselves at great ex-

58. See S. Rep. No. 1 139, 86th Cong., 2d Sess. (1960); S. REP. No. 621, 86th Cong., 1st Sess. (1959); S. REP. No. 1417, 85th Cong., 2d Sess. (1958).

59. S. Rep. No. 1417, 85th Cong., 2d Sess. 4 (1958).

60. Id. at 452 .

61. Contemporary commentators differed on the necessity for federal legislation to police union election abuses. Compare Cox, The Role of Law in Preserving Union Democracy, 72 HaRv. L. Rev. 609, 624-29 (1959), with Summers, Legal Limitations on Union Discipline, 64 HaRv, L. Rev. 1049, 1069-71 (1951).

62. See note 57 supra.

63. The most important differences between the House bill and the original KennedyErvin Senate bill were a reduction of the period for exhaustion of union remedies from four months to three, deletion of the word "reasonable" from the opportunity to nominate section, and other changes to assure that members' free speech was protected outside as well as inside the union hall. Goldwater, The Legislative History and Purposes of LMRDA, in Symposium, supra note 5 , at $32,34-35,52$.

64. S. 505, 86th Cong., 1st Sess. (1959). Senator Kennedy described the bill as a "modest proposal" that would protect union members "without undue interference in the internal affairs of what I believe are essentially private institutions-that is, American trade unions." 104 Cong. REC. 7954 (1958).

65. 105 Cong. Rec. 1259 (1959).

66. 404 U.S. 528 (1972). 
pense in multiple simultaneous suits and that the private enforcement procedure would permit the bringing of frivolous complaints, which the administrative enforcement procedure was intended to screen. ${ }^{67}$ The issue of private enforcement resurfaced in the House after the bill had passed the Senate, and the bill that passed the House provided for private actions to enforce election rights. ${ }^{68}$ The Senate's exclusive administrative enforcement model prevailed, however, in the Joint Conference Committee. ${ }^{69}$

Courts have relied on this history of consideration and rejection of private enforcement schemes, coupled with the purpose of Title IV as expressed by the Senate report-to allow only minimal federal interference in union affairs ${ }^{70}$-as authority for the proposition that Title IV's enforcement procedure is exclusive of all member suits in the post-election period. ${ }^{71}$ Because Title I was not considered until later, however, these arguments are conclusive only for private suits under Title IV, not for post-election Title I suits. $^{72}$

Title IV is directed at abuses associated with elections; its remedy for these abuses is a new election upon a showing that the violation might have affected the outcome of the election. A member's suit for vindication of a Title I right that does not seek to overturn an election is not within the area in which the Title IV remedy is exclusive. Just as Title IV could not be read to preclude an action for damages for an assault if the suit was in the post-election period and the assault preceded and was factually related to the election, it cannot be viewed to exclude analogous Title I suits if the legislative history of Title I demonstrates no congressional intent that such a result be required.

Senator McClellan originally introduced Title I after various labor reform bills had been debated over a course of almost two years, and after the Senate version of the LMRDA had already been thoroughly considered. ${ }^{73}$ In its original form, the bill did not

67. Id. at 532 .

68. H.R. 8342, 86th Cong., 1st Sess. § 402 (1959).

69. Joint Con. Rep. No. 1147, 86th Cong., 1st Sess. $\$ 402$, at 17 (1959).

70. S. Rep. No. 187, 86th Cong., lst Sess. 7 (1959).

71. See, e.g., Driscoll v. Operating Engineers Local 139, 484 F.2d 682 (7th Cir. 1973).

72. See also S. ReP. No. 187, 86th Cong., lst Sess. 21-22 (1959), indicating that the exclusivity applies only to the remedy of overturning an election.

73. The proposal came as a surprise to many Senators, who complained they were not given adequate time to research its provisions, 105 CoNG. Rec. 6697 (1959). The impetus for the amendment came from two sources-the American Civil Liberties Union and the Senate committee minority report that accompanied the Kennedy-Ives bill. The ACLU had been advocating such reforms for over a decade. See Leider, LMRDA and Its Setting, in SyMPosium, 
provide for member suits, but like Title IV, required suits to be brought by the Secretary of Labor ${ }^{74}$ Although Senator Kennedy and others objected on the ground that individual suits were necessary to provide union members with effective tools for enforcing their rights, ${ }^{75}$ the Members' Bill of Rights was initially passed with Senator McClellan's enforcement procedure. ${ }^{76}$

A new Bill of Rights, introduced by Senator Kuchel, improved some of the hastily drafted wording of the McClellan bill and eliminated the right of the Secretary of Labor to sue in the member's behalf. ${ }^{77}$ Several Senators expressed an intention by this change to assure that the Secretary of Labor did not "run every union." 78 The right of individual members to bring suit conflicted with the earlier endorsed Senate policy of permitting only minimal interference in intraunion affairs, but the Senate allowed that policy to yield in order to assure effective enforcement of Title I rights.

Neither the floor debates nor the Senate and House reports indicate a congressional intention to subsume the Title I enforcement procedures under those of Title IV in overlap cases. Indeed, the statements of several Senators concerning the desirability of independent proceedings under Title $I{ }^{79}$ viewed in light of the order in which the two titles were passed, can be read as indicating a contrary intent. The writings of several Congressmen, appearing soon after the enactment of the LMRDA, although not recognizing any interplay problem, exhibit concern over any limitation of union members' rights under Title I. ${ }^{80}$ Given this strong interest in

supra note 5 , at 12,14 . The Senate minority report cited the absence of a bill of rights as the reason for its conclusion that "[the Act] fails to achieve the objective which the American public demands." S. REP. No. 187, 86th Cong., 1st Sess. 70 (1959). For a slightly different analysis of the pressures that led to the passage of the LMRDA, see Cox, Internal Affairs of Labor Unions Under the Labor Reform Act of 1959, 58 MrCH. L. REv. 819, 820 (1960).

74. S. 1555, 86th Cong., 1st Sess. tit. I, § 3 (1959); see 105 Cong. Rec. 6976 (1959).

75. See 105 Cong. Rec. 6483 (1959) (remarks of Senator Kennedy).

76. See note 74 supra. See 105 Cong. REc. 6492 (1959). The bill was reconsidered, however, partly because of the fear that allowing interference by the Secretary of Labor might set a precedent for federal intervention that would be applicable in all civil rights matters. See Aaron, The Labor-Management Reporting and Disclosure Act of 1959, 73 HARv. L. Rev. 851, 859 (1960).

77. S. 1555, 86th Cong., Ist Sess. § 102 (1959) (as amended); see 105 Cong. Rec. 6720 (1959) (remarks of Senator Kuchel).

78. See, e.g., 105 CoNG. Rec. 6717 (1959) (remarks of Senator Javits); id. at 6721 (remarks of Senator Clark); id. at 6722 (remarks of Senator Cooper); id. at 6726 (remarks of Senator Kefauver).

79. See note 78 supra.

80. See, e.g., Goldwater, supra note 63, at 35; Roosevelt, LMRDA in the Congressional Arena, in Symposium, supra note 5, at 125, 128. 
full enforcement of Title I, a broad substantive preclusion based solely on overlap with Title IV is not justified by the legislative history of the LMRDA.

\section{A Resolution of the Interplay Problem}

An overbroad interpretation of the legislative intention to minimize governmental intrusions into union affairs and of the Supreme Court's holding in Calhoon v. Harvey has led some courts to deny relief to union members under a construction of the LMRDA that renders the Members' Bill of Rights virtually unenforceable in connection with union elections. A more rational approach to overlap cases, and one that is consistent with the statute, its legislative history, and the Court's holding in Calhoon, would be based on the principles that substantive preclusion of Title I claims because of Title IV's exclusivity of remedy is improper, and that preclusion of remedies in Title I suits is proper only when the individual member seeks to set aside or otherwise directly challenges an election already held.

The substantive scope of Title $I$ in relation to elections is narrower than the scope of Title IV, ${ }^{81}$ yet within its domain, Title I should be read so as to allow private suits regardless of any overlap. In enacting Title I, Congress intended to grant basic individual rights and to ensure the protection of those rights by allowing private enforcement. It is only in cases like Calhoon, where no violation of Title I rights is established and the only remaining cause of action would be under Title IV, that the exclusivity of enforcement under Title IV should justify dismissal of a member's suit.

If a valid Title I claim has been established, the second step is to inquire into the relief sought. The remedy for Title IV violations that may not be sought in a private suit is the setting aside of an election at the instance of the Secretary of Labor. Under section 403 , this "remedy ... for challenging an election already conducted" is exclusive. ${ }^{82}$ In overlap cases, however, it is consistent with both the language of section 403 and the legislative purpose to allow suits under Title I for relief even in post-election periods that does not constitute setting aside or otherwise challenging the election. In some ways, these remedies may be characterized as merely "pre-next-election" relief. Where, for example, a provision of the union constitution is alleged to violate Title $\mathrm{I}$, section $101(5)(\mathrm{b})^{83}$

81. See text and notes at notes 29-30 supra.

82. 29 U.S.C. $\$ 483$ (1970).

83. 29 U.S.C. $\S 411(5)(b)(1970)$. 
allows a private suit to invalidate the provision. The temporal relation of the suit to an election is irrelevant because the violation of the member's Title I rights is produced by the rule, irrespective of any particular election. ${ }^{84}$ This type of suit does not encroach on the ambit of litigation delegated exclusively to the Secretary and should therefore be permitted.

Similarly, a suit to enjoin all elections until the union's procedures are amended to comply with Title I guarantees of free speech and equal rights should not be dismissed automatically on the ground that the election pending at the time the suit was brought has been held, without independent consideration of traditional equitable criteria. If periodic elections are held or if the next election has been scheduled, relief can clearly be granted. ${ }^{85}$ The Title I claim is neither precluded by section 403 nor mooted, since the prospective relief sought is not tied to the particular election already conducted.

In the Driscoll case, ${ }^{86}$ the Seventh Circuit found Driscoll's Title I claim precluded by an overlapping Title IV violation. Under the first step in the recommended analysis, this overlap would have been irrelevant in determining the substantive sufficiency of the claim. The court noted that there were arguable violations of both titles; it should have allowed the district court to exercise jurisdiction over the independent Title I allegation. ${ }^{87}$

The second step in the recommended analysis requires consideration of the remedy sought. Driscoll requested the district court to enjoin the union from requiring candidates for office to sign the anticommunist affidavit. This injunction was not tied to a particular election, and should not have been held barred by Title IV's exclusivity of remedy. Under the analysis recommended in this comment, the case should have been remanded for trial on the merits. If the district court found that there had been a denial of the member's free speech or equal right to vote or nominate as

84. Even where the relief sought relates more closely to the election, as in the case of a suit for damages for violation of Title I rights during the conduct of an election, preclusion is arguably improper. The damages are asked for the denial of individual rights, and a broad challenge of the election like that involved in a suit to set aside the election is not presented. Thus, the remedy should not be precluded under Title IV.

85. But cf. Robins v. Rarback, 325 F.2d 929, 929, 934 (2d Cir. 1963) (declaring appeal from denial of motion for preliminary injunction of election moot because election had been held, although next election was scheduled to be held six months later).

86. See text and notes at notes 31-43 supra.

87. But see Driscoll v. Operating Engineers Local 139, 484 F.2d 682, 686 n.9 (2d Cir. 1973). The court read Calhoon as precluding jurisdiction over an individual member's complaint where it states a putative Title IV claim. 
guaranteed by Title I, it should have granted the injunction against the union.

\section{CoNCLUSION}

The interplay of Title I and Title IV of the LMRDA has continued as a source of confusion. Relying on the Supreme Court's decision in Calhoon, courts have reached contradictory results in overlap cases. The dominant approach has been to regard Title IV as precluding private Title I suits. This comment has argued that this result is required neither by the legislative history of the statute nor by Calhoon. Instead, it has suggested that a simple two-step analysis, involving independent examination of claims under Title I and application of a rule of preclusion only in terms of the remedy sought will serve to enforce the statutory purpose of providing members a means of vindicating their rights without undue disruption of internal union affairs.

James $M$. Harris 